\title{
REFLEXÕES DE UMA ANTROPÓLOGA "ANDARINA" SOBRE A ETNOGRAFIA NUMA COMUNIDADE DE MINEIROS DE CARVÃ̃*
}

\author{
Marta Cioccari \\ Universidade Federal do Rio de Janeiro - Brasil
}

Resumo: Ancorada em minhas experiências de campo na comunidade de mineiros de carvão de Minas do Leão (RS) - e também na Lorena francesa -, analiso neste artigo a dimensão da subjetividade do pesquisador, considerando os estudos de Devereux (1980) sobre as "observações recíprocas" que se operam entre etnógrafo e nativos e as perturbações mútuas daí derivadas, que remetem a conhecimentos específicos sobre a interação. As reflexões consideram minha condição de gênero, de ser uma mulher investigando um universo masculino, e se alicerçam ainda em diferentes dimensões de minha trajetória e nos ecos que essas identidades suscitam entre meus interlocutores. Adotando a noção de "ser afetado" (être afecté) proposta por FavretSaada (1990), exploro ainda os insights suscitados por sonhos em diferentes contextos da pesquisa, reveladores de novos aspectos acerca da experiência etnográfica.

Palavras-chave: etnografia, mineiros de carvão, observação recíproca, subjetividade.

Abstract: Anchored in my experiences of field in the community of coal mining of Minas do Leão city (RS) - and also in the French Lorena -, I analyze in this article the dimension of the subjectivity of the researcher, considering the studies of Devereux (1980) on "specific comments" that ethnographer and natives are operated between and the mutual disturbances derivatives of this, that they send the specific knowledge on the interaction. The reflections consider my condition of gender, of to be a woman investigating a masculine universe, and still strengthen in differents dimensions of my trajectory and the echoes that these identities excite between my interlocutors. Adopting the notion of "to be affected" (être afecté ) proposal for Favret-Saada

* Agradeço a José Sergio Leite Lopes, Indira Caballero, Fernanda Figurelli e Rogério Azize, pelo estímulo e as preciosas sugestões. A Laura Chartain e a Jean-Pierre Faguer, pela interlocução em torno de entrevistas feitas na França. Sou grata ainda aos informantes de Minas do Leão e da Lorena francesa.

Horizontes Antropológicos, Porto Alegre, ano 15, n. 32, p. 217-246, jul./dez. 2009 
(1990), I still explore insights excited by dreams in differents contexts of the research, revealers of new aspects concerning the ethnography experience.

Keywords: coal miners, ethnography, mutual observation, subjectivity.

Quando fui morar em Minas do Leão, cidade de mineiros de carvão no Rio Grande do Sul, para conduzir minha pesquisa, percebia que a consciência de que minha presença seria impermanente, provisória, gerava certa inquietação entre meus interlocutores. Muitos deles estranhavam meu modo de vida, de uma pesquisadora que "mora um pouco em cada lugar", "como cigano". Alguns não hesitavam em me perguntar sobre "quando eu iria me assentar", ou sugerir-me que talvez eu pudesse ficar morando ali, já que, segundo uma crença local, "quem bebe água da sanga da Taquara não vai mais embora". Certa vez, um ex-mineiro usou um termo peculiar: "Tu é uma andarina", ele me disse, lançando mão do termo tomado do espanhol que ali se mistura à fala cotidiana. A palavra andarina reúne três significados: ${ }^{1}$ o de andarilho, pessoa anda muito sem se fixar; o de mensageiro, que leva cartas ou notícias; e o que diz respeito à andorinha, a ave que simboliza o "eterno retorno", pois parte no inverno e retorna no verão. Traduz bem o movimento do etnógrafo: do esforço de peregrinação nos mundos a que nos lançamos, das trocas objetivas e subjetivas, e dos inúmeros deslocamentos entre o campo e a escrita.

Neste artigo, reflito sobre as "perturbações" mútuas causadas pela presença do pesquisador no campo, considerando-as, como sugere Devereux (1980), não como ruídos indesejáveis, mas como parte importante e rica de uma interação recíproca, capaz de fornecer preciosos insights, que não poderiam ser obtidos de outra maneira. ${ }^{2}$ Essa análise inspira-se nas formulações de Devereux sobre a forma como a angústia experimentada pelo pesquisador diante de determinados dados - a chamada contratransferência ${ }^{3}$ - pode ser

\footnotetext{
Dicionário da Real Academía Española.

Ver também Caballero, Cioccari e Figurelli (2007).

Conforme Devereux (1980, p. 75), o termo psicanalítico contratransferência diz respeito às deformações que afetam a percepção do analista em relação a seu paciente - ou do etnógrafo em relação a seu nativo. $\mathrm{O}$ analista, como o etnógrafo, responde a seu interlocutor como se este constituísse uma imago primitiva (a idealização de uma pessoa na infância que se conserva na vida adulta) e então se comporta em função de suas próprias necessidades inconscientes. É por uma convenção que se denomina transferência as reações do analisado ou informante e contratransferência as do analista ou etnógrafo.
}

Horizontes Antropológicos, Porto Alegre, ano 15, n. 32, p. 217-246, jul./dez. 2009 
convertida em conhecimento. São desse autor análises pioneiras sobre como o gênero, a profissão, a condição social e a idade do pesquisador podem condicionar os papéis que os nativos tendem a imputar-lhe - e que, caso sejam aceitos, lhe permitirão o acesso a determinados dados a partir de um certo ponto de vista. Inspiro-me ainda no que escreveu Favret-Saada (1990) sobre o etnógrafo aceitar "ser afetado" pelo campo.

O que está em jogo nessas noções é o reconhecimento da subjetividade do observador e a aceitação de que sua presença influencia o evento pesquisado - de forma que ele jamais observa o comportamento que "teria lugar em sua ausência" (Devereux, 1980, p. 30). Manuais de pesquisa de campo têm se apoiado nesde autor, destacando a importância da "explicitação das condições singulares de pesquisa" a que o etnógrafo está sujeito, na medida em que os dados de uma pesquisa só são analisáveis em seu contexto de produção (Beaud; Weber, 1998). Como acentua Foote Whyte (2005, p. 283), quando um pesquisador vive longo tempo na comunidade que estuda, "sua vida pessoal estará inextricavelmente associada à sua pesquisa". Assim, uma explicação sobre a pesquisa envolve uma narrativa pessoal sobre como o pesquisador viveu aquele período.

Durante a etnografia, habitei durante seis $\operatorname{meses}^{4}$ na comunidade de Minas do Leão, numa casa situada na antiga vila mineira. Nessa localidade de cerca de oito mil habitantes - como em outras estudadas por antropólogos em âmbito internacional (como Eckert, 1985, 1991, 1992; Schwartz, 2002) a mina consiste num mundo de referência, a partir da qual se formou a vila operária, fornecendo um ethos aos trabalhadores. Devido ao fechamento da última mina subterrânea, em 2002, e ao evento da aposentadoria para muitos operários, é possível notar como as preocupações voltam-se para a vida privada, para as atividades lúdicas, como jogos e apostas, para as práticas religiosas e para as relações familiares e de vizinhança. Nesse contexto, eram constantes as atitudes e referências verbais que punham em jogo questões de gênero relativas à minha presença, de uma pesquisadora mulher interessada em trajetórias masculinas.

Para se entender a importância das questões de gênero na localidade é preciso levar em conta alguns aspectos. Predomina ali uma noção de

4 Entre setembro de 2006 e fevereiro de 2007. 
masculinidade voltada para a afirmação da coragem, da força, da virilidade e ancorada na figura do pai-marido, do provedor, a exemplo do que vários estudiosos têm indicado entre classes populares (Duarte, 1986, 1987; Eckert, 1985; Fonseca, 2000; Guedes, 1997; Kimmel, 1998; Leal; Boff, 1996). Em Minas do Leão, o modelo de masculinidade dominante exacerba a exibição de virilidades por meio de brincadeiras, ${ }^{5}$ de disputas corporais e verbais. Nesse sentido, o "brinquedo" e as provocações configuram-se como uma linguagem. É recorrente entre as mulheres a representação em torno de uma "natureza masculina" (Knauth, 1998; Pitt-Rivers, 1983), uma noção que permite aos homens usufruir com certa legitimidade de um amplo espaço de liberdade, embora a "vigilância" feminina esteja sempre presente. Algumas mulheres destacavam a sua "esperteza" em não dar demonstrações de que sabem que estão sendo traídas. Mais do que uma visão romântica, impera um sentido prático do casamento. ${ }^{6}$ Numa ocasião, escutei uma mulher aconselhando à amiga: "Tu vai ser boba de perder o conforto da tua casa por bobagem?" No entanto, em caso de separação, se a nova mulher daquele homem lhe "põe chifres", isso pode ser comemorado pela ex-mulher como "vingança". Do lado masculino, há a recorrência de narrativas autoelogiosas. Eles se gabam de suas performances falando geralmente a outros homens sobre conquistas amorosas, sejam reais, exageradas ou inventadas. Percebi que tais comportamentos não são específicos de uma fase da vida, mas podem ser notados em diferentes faixas etárias.

Trata-se de uma comunidade na qual as noções de família, a exemplo de outras estudadas por antropólogos no Brasil (Comerford, 2003; Fonseca, 2000), são centrais e conformam diferentes relações, envolvendo não apenas o parentesco "de sangue", o casamentos entre primos, mas também as adoções e as relações de compadrio (Pitt-Rivers, 1983). A noção de amizade aparece caracterizando a intimidade da convivência no subsolo, mas os mineiros preferem dizer que lá "era uma irmandade", era-se "como uma família". A importância atribuída à família e ao casamento era expressa através de recorrentes perguntas feitas a mim: "Tu tem parentes aqui?", " "tu é parente deles?" (referindo-se ao casal que me acompanhava). E ainda: "Tu é casada?" Diante

\footnotetext{
5 Ver Hoggart (1973), Eckert (1985), Duarte (1987), Leite Lopes (1988) e Comerford (2003).

6 Sobre a figura da "mulher interesseira", ver Fonseca (2000).

7 A situação é similar à narrada por Comerford (2003).
} 
de uma negativa: "Mas já foi casada?" O episódio no qual recebi a visita de um amigo, ex-aluno interessado em conhecer aquele universo, foi revelador. Nos dias que se seguiram, fui questionada por vizinhas se o visitante era meu irmão. Uma delas disse: "Eu pensei, só pode ser irmão dela, de tão parecido..."; outra: "É teu irmão aquele rapaz que esteve aqui?"; e uma terceira: “A gente pensou: 'Deve ser irmão mais novo dela'!" O que se via é que a noção de amizade não era evocada naturalmente como a de família.

Tais questões levaram-me a desenvolver algumas reflexões, afloradas em mútuas e contínuas observações que não se dão sem algum constrangimento e tensão. Como nos ensina Devereux (1980, p. 19), durante o trabalho de campo, o que dá acesso à essência da situação da observação não é exatamente o estudo do sujeito, mas o do observador. Os dados das ciências do comportamento apresentam-se em três formas: o comportamento do nativo; as perturbações induzidas pela existência do observador e por suas atividades; e o comportamento do observador, suas angústias, manobras de defesa, estratégias de pesquisa e decisões (com a atribuição de sentido às observações). Esses últimos aspectos nem sempre integram legitimamente os estudos etnográficos.

Ainda que o controle social me fosse incômodo, parecia ser a contrapartida da minha própria investigação sobre a vida dos moradores, e tinha por objetivo verificar o grau de confiança, de credibilidade que poderia ser depositado em mim como pessoa e no trabalho que eu desenvolvia. Não sendo parente de ninguém e não me encaixando nos papéis atribuídos às mulheres, eu estava exposta à desconfiança. Havia, ainda, o aspecto de ser uma "mulher solteira”. Morando sozinha em uma casa situada numa esquina, experimentei a desconfortável sensação de passar de observadora a observada, não apenas pela intensa curiosidade demonstrada por quem passasse na rua, mas de tornar-me alvo mesmo da vigilância de vizinhas, ${ }^{8}$ que prestavam uma atenção, que sempre me pareceu exagerada, a meus movimentos. Eu adotava uma atitude de simpatia, mas também de certo recato - isso se refletia na escolha das vestimentas e na condução das interações. Só mais tarde vim a entender que esse controle fazia parte da construção de minha reputação. Como define Bailey (1971, p. 4), a reputação de uma pessoa não é uma qualidade que ela possui, mas a opinião que as outras pessoas têm dela. Nos grupos com os quais

8 Sobre o controle social exercido pelas mulheres, ver Hoggart (1973) e Fonseca (2000).

Horizontes Antropológicos, Porto Alegre, ano 15, n. 32, p. 217-246, jul./dez. 2009 
estabeleci laços de afeto, depois escutei dizerem: "Ela já é da família”, "ela é como uma filha", ou "é como uma irmã pra gente".

Vencida a etapa do estranhamento, passei a ser convidada pelas esposas de casais vizinhos para "ir a um baile" com eles, onde poderia "conhecer alguém". A situação de habitar durante longo tempo aquela cidade me colocava na condição de uma espécie de "moradora", alguém a quem é preciso ajudar a se instalar, a criar raízes na comunidade, a "se assentar", a constituir - também, por sua vez - uma família. O convite para frequentar bailes era a maneira pela qual mulheres da localidade expressavam seu acolhimento, sua aceitação a uma "estranha". Nessa atitude exibiam também noções profundamente entranhadas que remetem o feminino à vida familiar, enquanto a centralidade do trabalho seria algo do mundo masculino. Esse tipo de solidariedade feminina pode embutir uma tentativa de familiarização e/ou domesticação da alteridade e de neutralização de fatores que poderiam significar concorrência junto aos homens.

Quando se examinam os modos pelos quais o observador é esquadrinhado em campo, é preciso considerar o que diz Devereux (1980) sobre o fato de que, no trabalho etnográfico, trata-se de uma observação recíproca, na qual tanto o pesquisador como os nativos agem como observadores. É uma convenção que estabelece que "A é um observador" e "B é um observado". Devereux (1980, p. 61, tradução minha) alerta "cada um dos dois é para ele mesmo 'observador', e 'observado' para o outro”, de forma que todas as perturbações resultam dessa experiência dupla, que tem o mérito de remeter o antropólogo à auto-observação e à consciência da complexidade da interação.

Em vez de lamentarmos a perturbação devida à nossa presença no campo e em vez de colocarmos em dúvida a objetividade de toda a observação do comportamento, deveríamos observar a dificuldade de uma maneira construtiva e descobrir quais insights positivos, não suscetíveis de serem obtidos por outros meios, podemos tirar do fato de que a presença de um observador, que é da mesma ordem de grandeza daquele que ele observa, perturba o evento observado. (Devereux, 1980, p. 369, tradução minha, grifo do autor).

Tais questões influenciaram o estudo de Schwartz (2002) sobre a vida de operários em antiga região mineira do Norte da França. Baseando-se em Devereux (1980), ele notava que a contraobservação do pesquisador pelos 
nativos "está no princípio de um esforço contínuo de elaboração de sua própria imagem, destinada a impor certa representação deles mesmos àqueles que os observa". (Schwartz, 2002, p. 41, tradução minha). Ele adotou as noções de "perturbação utilizada" e de "perturbação reduzida". A primeira atitude consistindo em considerar a "perturbação" não como um obstáculo epistemológico, mas como uma forma de conhecimento. A segunda buscava minimizar os efeitos da intimidação devida à sua presença (Schwartz, 2002, p. 47).

\section{Dos riscos para a reputacão}

Ao longo de minha investigação, interagi com cerca de 40 famílias. ${ }^{9}$ A convivência com as mulheres me ajudou a compreender complexidade da vida privada. Uma parte dos conflitos narrados por elas envolvia, como foi dito, a "traição" masculina. A temática do "corno" (do adultério feminino) era explorada geralmente por homens, referindo-se a "outros". Ainda que esses aspectos fossem abordados livremente, as tentativas de aprofundamento revelaram-se vez por outra arriscadas. O que estou considerando como risco é o que pode suscitar de mal-entendido uma mulher mostrar interesse nessas questões. Em uma entrevista com um viúvo de cerca de 80 anos, uma pergunta sobre o porquê da recorrência das "histórias de cornos" na comunidade abriu o leque para uma série de revelações de caráter íntimo, nas quais o entrevistado se gabava de suas próprias aventuras amorosas. A lógica dessas narrativas redundava na adjetivação de "cornos" a antigos colegas, com cujas esposas ele teria tido envolvimentos. Constrangida pelo tom explícito das confidências, eu ensaiava o fim da entrevista, quando ouvi: "Pode voltar a me entrevistar, mas é perigoso, porque eu sou viúvo." Com um gesto sugerindo cumplicidade, completou: "Não tem problema, né, tu é solteira." A noção da viuvez como "perigosa" apareceu em outras situações, com caráter mais ou menos jocoso. Tal representação parece estar vinculada ao principal papel que tais homens sabem jogar, que os protege da desfiguração de outras identidades - em especial a de mineiros, em vias de desaparecimento - assim como da ameaça simbolizada pelo envelhecimento e pela solidão à imagem de virilidade, tão valorizada socialmente.

9 Totalizando 60 entrevistas.

Horizontes Antropológicos, Porto Alegre, ano 15, n. 32, p. 217-246, jul./dez. 2009 
De outro modo, alguns dos possíveis erros ou gafes que cometi em campo provocaram agudos questionamentos sobre os limites de minha inserção. Numa ocasião em que eu estava interessada em conhecer as modalidades de jogos tais como as "apostas eleitorais" (Palmeira, 2006), fui convidada por um amigo, filho de um informante, para um jantar de pagamento de uma aposta deste tipo. Era uma boa oportunidade para observar esse aspecto no período que se seguia às eleições presidenciais de 2006. No horário combinado, o amigo esperou-me diante de minha casa, sem mesmo entrar no pátio, como convinha aos hábitos locais. As convenções rezam que, se um homem entrar na casa de uma mulher solteira dará origem a fofocas e mexericos. Daí por diante eles serão vistos como "amantes" ou, ao menos, estará lançada a dúvida sobre a conduta "dela".

Saímos caminhando a pé, mas logo adiante conhecidos dele nos ofereceram uma carona. Quando chegamos ao local, um bar-snooker que poderia ser chamado de "pé-sujo", eu percebi que, entre os convivas, seria a única mulher presente. Eu não sabia que, além do pagamento da aposta, tratava-se de um dos encontros semanais "só para homens" promovidos pelos jogadores veteranos do Atlético Futebol Clube, um dos times de futebol organizados em torno das minas que mais tarde eu teria a chance de pesquisar. Perguntei ao amigo que me acompanhava: “Sou a única mulher?” Ele respondeu: “É, mas tu veio a trabalho." Quando entrei no recinto, cerca de 30 pares de olhos estavam voltados para mim. Disfarcei meu constrangimento como pude e logo reconheci alguns informantes que se levantaram para me cumprimentar. Estavam ali mineiros, funcionários da companhia de mineração, um engenheiro, políticos e empregados em outras atividades. O perdedor da aposta convidou a que me servisse da refeição. Enquanto o fazia, encontrei um engenheiro com quem eu havia falado dias antes: "Quer dizer que estás pesquisando tudo mesmo?!", disse-me com certa malícia. No bar sobre o chão batido, identifiquei três ambientes: um dos que jogavam snooker, outro dos que estavam jantando, sentados em bancos dispostos ao longo da mesa, e um terceiro, de uma roda de samba, na parte à esquerda do "L" invertido que era o formato da peça. Além de mim, a única mulher era a cozinheira. Depois de jantar, sentei num canto da mesa e comecei a tomar notas ouvindo os apostadores. O vencedor, que havia "jogado" na vitória de Lula, tinha sido entrevistado por mim anos antes, quando era prefeito da cidade. O derrotado na aposta era um ex-mineiro que se tornara produtor rural, casado com uma vereadora. 
Apesar do mal-estar vivido, só entendi de fato o tamanho da transgressão que havia cometido quando, no dia seguinte, retornando de um jogo de futebol a que fui assistir com o mesmo amigo, encontramos uma mulher que ele me apresentou como sendo esposa de um dos veteranos do Atlético. Com certo humor, ela me disse que seu marido havia contado sobre minha a presença no local, sobre "uma mulher que estava lá entrevistando um e outro". Ali fiquei sabendo que as mulheres tinham o seu próprio "clube das Luluzinhas", que promovia encontros nos quais os homens não entravam. Dias depois, ao encontrar com a esposa de outro participante, voltei a falar sobre o encontro no bar. Ela me disse que seu marido havia comentado sobre o ocorrido assim que chegou em casa. Tais detalhes revelavam quão estranha fora considerada a minha presença. Aqueles homens estavam preocupados com sua reputação: se as esposas soubessem de outro modo sobre uma presença feminina no local poderia haver desconfianças sobre o caráter daquelas reuniões, consideradas como uma "instituição" local. Ainda que minha ação tenha sido creditada ao fato de eu ser "de fora" e, possivelmente, por "estar a trabalho", não contribuía para me aproximar das mulheres. Quando fui convidada a viajar com o grupo a uma localidade onde disputaria uma partida de futebol, decidi recusar. Seria uma observação de grande valia, mas não estaria livre de novos embaraços.

Tudo isso é vivido sob uma forte carga de tensão e ansiedade, considerando os riscos de que uma ação equivocada possa "fechar o campo". As observações de Devereux (1980, p. 162, tradução minha) lançam luz sobre esse aspecto quando referem que "o sexo do etnógrafo é levado em conta para determinar o que lhe será permitido ver". Ou seja, o gênero do pesquisador restringe a gama de situações nas quais ele pode se comportar como observador participante. $\mathrm{O}$ autor ressalta, porém, que essas barreiras podem ser minimizadas pelo fato de o pesquisador ser um estrangeiro ao local. E sendo o forasteiro o sujeito "esquisito" que é o antropólogo, cujos objetivos só são parcialmente compreendidos, ele pode ser tratado como "neutro", sendo-lhe permitido ver coisas que, caso pertencesse ao grupo, lhe seriam interditas. Interessa-me aqui explorar fatores que podem remeter a uma neutralidade de gênero. Ao longo do tempo tornou-se público meu interesse em estudar a organização dos clubes de futebol ligados às minas, legitimando assim minha aproximação com o grupo. Uma parte de minha pesquisa acabou por basear-se justamente na relação entre a mina e as equipes de futebol. Mais tarde, fui intermediária entre o grupo e uma rede nacional de televisão para um documentário sobre 
os mineiros-jogadores. Nessa altura, eu havia me convertido numa espécie de "camarada", desempenhando um papel mais próximo do universo masculino do que do feminino. Tentando calcular os riscos de minhas ações, noutra vez perguntei a um informante se "ficaria bem" eu ir a outro evento que seria frequentado por homens. Sua resposta apaziguou minhas angústias: "Tu é uma jornalista, ${ }^{10}$ pode ir a qualquer lugar. Está fazendo o teu trabalho." Se poucos informantes saberiam dizer que eu era "uma antropóloga", todos compreendiam que "uma jornalista" precisa circular para colher informações. Ainda que eu explicasse a diferença entre meu trabalho anterior e o da pesquisa que fazia naquele momento, não raro ouvia sugestões para "minha reportagem".

Um aspecto enfatizado por Guedes (1997) e por Machado (2007) é de que a posição "peculiar" de ser uma mulher pesquisando homens num meio popular não diz respeito apenas a dificuldades, mas representa também riquezas adicionais. Como ressalta Kimmel (1998), a construção da masculinidade se dá tanto nas relações com os outros homens ${ }^{11}$ como com as mulheres. Parece-me que, em certa medida, os informantes podem mesmo "encenar" com a pesquisadora interações que imitam seus relacionamentos. Certa vez, um informante me contou, rindo, que por me acompanhar em entrevistas estava sendo alvo de brincadeiras. Um dos companheiros lhe disse: "Ela é muita areia pro teu caminhãozinho!" Ele não se fez de rogado: "Não tem problema, faço várias viagens", retrucou. Ao me relatar isso, porém, agregava: "Mas imagina só o que tu ia querer com um mineiro pobre-diabo..." Eu lhe disse que a questão não era ser ou não mineiro, mas que, por uma questão ética, eu não me envolvia com informantes. O que era perceptível é que, me acompanhando em alguns contatos, meu interlocutor considerava haver um acréscimo de seu "prestígio", o que lhe permitia "se gabar" dessa relação.

\section{Da observação participante ao "ser afetada" pelo campo}

Em minha investigação, adotei a técnica das entrevistas semiestruturadas e das entrevistas abertas e biográficas, atenta para as narrativas construídas pelos interlocutores a partir de sua perspectiva, que, compartilhando traços

\footnotetext{
${ }^{10}$ Anos antes, eu havia ingressado na comunidade na condição de jornalista.

11 Parker (1991, p. 74) observa que a construção do masculino se dá também por relação ao "machão", ao "corno" e ao "viado".
} 
com a biografia e a autobiografia, ${ }^{12}$ acabam por compor-se como "um mosaico" (Becker, 1993). Essas histórias de vida representam mais do que um itinerário singular, são "reveladoras dos modos de participação numa cultura, num métier, numa condição" (Balandier, 1991, tradução minha). Cada narrativa traduzia também singularidades dos percursos, com uma diversidade de elementos: origem rural ou urbana, pertencimento religioso em vasta gama de opções, laços familiares estruturando carreiras políticas e esportivas, etc.

O método etnográfico, na tradição inaugurada por Malinowski (1984), sempre foi uma referência primordial. O autor destacava três momentos do trabalho de campo. Primeiro, a busca de conhecimento sobre o "esqueleto da vida social". Segundo, uma vivência intensa e prolongada em campo, buscando conhecer seus hábitos, rituais, afazeres e lazeres, onde se buscaria captar a "carne e osso do nativo", junto aos "imponderáveis da vida real". E, então, o registro de sua visão de mundo, das opiniões, das palavras, o esforço para se conhecer o modo de pensar e de sentir do nativo (Malinowski, 1984, p. 36-37). Malinowski (1935) propôs uma "teoria etnográfica da linguagem", que consiste em recolocar os enunciados nos contextos práticos nos quais eles ganham sentido. As questões de subjetividade e da forma como foi afetado pela relação com os nativos vieram à tona posteriormente em seu diário (Malinowski, 1989).

O fundamento da observação participante, como nota Durham (1978, p. 47), estaria nesse processo de transformação do observador, "que consiste na assimilação das categorias inconscientes que presidem à ordenação do universo cultural investigado". Ela acentua que o pesquisador altera-se a si próprio, transformando-se num instrumento de investigação. Por sua vez, Cardoso de Oliveira (2000) menciona o poder "extraordinário" que o etnólogo exerce sobre o informante, ainda que pretenda posicionar-se da forma mais neutra possível. Ele propõe que o informante seja transformado em "interlocutor", inaugurando uma relação dialógica que faria com que "os horizontes semânticos em confronto" pudessem abrir-se um para o outro, transformando-se num "verdadeiro encontro etnográfico". Nesse espaço partilhado, poderia haver a "fusão de horizontes" (Cardoso de Oliveira, 2000, p. 23-24).

12 Ver Foote Whyte (2005), Leite Lopes e Alvim (1999), Viseux (1991), Mintz (1979, 1984), Malva (1978) e Nash e Rojas (1976). 
Parece-me, entretanto, que se pode falar menos de fusão do que de produção múltipla de novas percepções nos diferentes mundos que nativos e pesquisador habitam. Explicita-se o poder que o pesquisador exerce sobre os informantes, mas é preciso considerar ainda o modo pelo qual o próprio observador é atingido pela experiência. DaMatta (1978, p. 24) mostrou que o conhecimento no campo é permeado por cheiros, cores, dores, amores, ansiedades, medos, todos esses "intrusos" que não constam dos manuais. Caldeira (1981) apontou questões cruciais acerca da subjetividade tanto do entrevistado como do pesquisador. As angústias que remetem a um sentimento de "traição" da confiança dos nativos, na sua objetivação pela escrita, foram evidenciadas por Bourdieu (2005) e por Schwartz (2002).

A meu ver, Favret-Saada (1990) extraiu verdadeira riqueza das perturbações no seu campo, pesquisando feitiçaria no Bocage francês. Ela descobriu que os nativos somente aceitaram partilhar sua experiência quando pensaram que ela tinha sido afetada pelos efeitos da feitiçaria. A metodologia que adotou não era nem de observação participante, nem de empatia. Em campo, não pôde fazer outra coisa a não ser "se deixar afetar pela feitiçaria" (Favret-Saada, 1990). Um etnógrafo aceitar "ser afetado" não implica que ele se identifique com o ponto de vista nativo. O ponto de partida é o reconhecimento de que a comunicação etnográfica ordinária - verbal, voluntária e intencional, visando ao aprendizado de representações - é insuficiente e imprópria para captar os aspectos não-verbais e involuntários da experiência humana. Mas é preciso que o pesquisador tolere viver uma experiência "esquizo" - que aceite a ambivalência de, ora ser afetado, ora registrar essa experiência e tentar compreendê-la. Em minha experiência, insights surgiram de situações em que considero ter sido "afetada" pela experiência, fosse na ocasião de minha conversão à antropologia, fosse pelo impacto da interação com os nativos. Comunicações involuntárias ocorreram em sonhos, como examino a seguir.

\section{Os sonhos da iniciação}

Inicialmente, descrevo as cenas de dois sonhos que considero interligados, ocorridos no final de 2002. Esses sonhos reúnem fortes elementos simbólicos relacionados à minha "iniciação" como antropóloga. ${ }^{13}$ No primeiro

${ }^{13}$ Cf. Cioccari (2004, f. 5-6). 
sonho, eu via um par de botinas de couro marrom-escuro, cuja parte posterior estava escrito: Charbon. Elas me tinham sido emprestadas pela professora que seria minha orientadora de mestrado e que com elas havia percorrido os mundos de mineiros franceses ${ }^{14}$. Mais tarde, ela me relatou que, na sua pesquisa de campo junto a uma comunidade de mineiros de carvão na França (19871991), usava botinas semelhantes a essas. O empréstimo efetivo foi de uma centena de livros, a maior parte sobre minas da França. Em outro sonho, essa antropóloga me mostrava uma capa bege-clara. Por fora, era de uma gabardina impermeável. Mas o que fixou minha atenção foi o seu interior. O forro era feito de um tecido espelhado: nele se podia ver a própria imagem. Sugeria o efeito invertido pelo qual quanto mais mergulhamos no conhecimento do "outro", mais esse movimento nos remete a nós mesmos, às nossas profundezas. Depois descobri a metáfora da "capa do antropólogo". ${ }^{15}$

\section{0 sonho da castração}

Quando se passou o episódio que vou narrar, eu já havia começado o trabalho de campo, mas ainda não dispunha de moradia em Minas do Leão. Disposta a passar ali o fim de semana, hospedei-me num hotel numa cidade próxima. Também ali eu tinha informantes, em especial um mineiro que, anos antes, havia colaborado numa reportagem. Naquele sábado, fui encontrá-lo na mina levando algumas fotos. Depois do encontro, aceitei uma carona sua até a cidade vizinha, onde eu estava hospedada. No trajeto, fui surpreendida pelas confidências sobre as diversões dos mineiros, que incluíam visitas a zonas de prostituição. Ele reclamava que as esposas já não consentiam na liberdade que havia na época de seu pai. Eu ouvia um tanto desconfortável diante das revelações inesperadas e do discurso "machista". Era uma conversa bastante calcada na masculinidade. Carismático, esse informante mantinha uma atitude entre cortês e sedutora, que dispensava também às colegas da empresa. Ao deixar-me em frente ao hotel, fez um convite para que eu o acompanhasse num churrasco. Achei mais prudente não aceitar. Ser a única mulher no evento masculino não seria um bom começo de pesquisa. Naquela noite, recolhida ao

\footnotetext{
${ }^{14}$ No mestrado fui orientada por Cornelia Eckert defendendo a dissertação (Cioccari, 2004).

15 DaMatta (1978) adota a expressão "vestir a capa de etnólogo".
} 
hotel, tive um sonho estranho. Meu interlocutor aparecia-me e, como vestia apenas um calção de trabalho, vi que sangrava. Em minha consciência de sonho, eu sabia que estava embriagado e que havia tentado castrar-se. Acordei um tanto aturdida com a nitidez da imagem.

Antes de nos despedirmos, no final de tarde, havíamos combinado que, no sábado seguinte, eu o encontraria na rodoviária para irmos à casa de um ex-mineiro que me seria apresentado por ele. As imagens do sonho retornaram durante a entrevista com o novo informante, quando o ex-mineiro, junto com a mulher, passou a me contar uma brincadeira que ocorria no subsolo. Era a história do "carrasco da mina", uma espécie de ritual de castração em que um grupo de mineiros liderado por ele - o dono da "faquinha azul" - amarrava num canto escuro da mina um companheiro que se gabasse de seus feitos sexuais. Depois de desnudado, ameaçavam cortar seus genitais. Tudo era permeado por tanto realismo que as vítimas entravam em pânico. No relato, aquilo era "uma brincadeira", ${ }^{16}$ como outras brutas do seu cotidiano. Essa brincadeira servia assim para coibir os excessos, vividos e/ou narrados, daqueles que "gostavam de se gabar, de contar vantagens" sobre conquistas amorosas. Quero chamar a atenção para a "comunicação involuntária" (Favret-Saada, 1990) que penso ter estabelecido sobre um tema-tabu naquele contexto. O sonho está ligado a uma experiência de "angústia", nascida, para usar os termos de Devereux (1980, p. 79, tradução minha), "daquilo que é experimentado como uma 'hiper-comunicação', relacionada ao inconsciente do observador e daquele que é observado".

Vale retornar ao que diz Devereux sobre como o gênero do observador afeta a pesquisa. Ele contraria uma opinião segundo a qual as mulheres pesquisariam melhor as próprias mulheres e os homens, os informantes masculinos. Afirma que uma melhor informação sobre sexualidade parece ser obtida por um etnógrafo do sexo oposto ao do nativo. Para ele, "uma entrevista sobre o tema da sexualidade, mesmo que se trate de uma pesquisa científica, é ela mesma uma forma de interação sexual":

[...] a maior parte das pessoas sendo considerada como heterossexual, um informante dará uma informação melhor e, sobretudo, pluridimensional a um etnógrafo do sexo oposto. [Além disso] [...] toda conversação privada entre duas

${ }^{16}$ Cf. Cioccari (2004). 
pessoas de sexo oposto, mesmo se ela não é necessariamente, ou segundo as normas objetivas, orientada para a sexualidade, pode ser interpretada nesse sentido por vezes pela pessoa entrevistada e pela sociedade. (Devereux, 1980, p. 160, tradução minha).

Baseando-se em Devereux, Bozon (1995) assinala que, num ambiente heterossexual, o fato de os confidentes serem do mesmo sexo pode "ser interpretado como um meio, para eles, de se proteger das implicações sexuais da confidência". Assim, numa conversa sobre sexo, cada um escolhe "o que diz e a quem diz" (Bozon, 1995, p. 41). Ele analisa circunstâncias em que há uma resistência do informante a explorar aspectos da vida sexual diante de um pesquisador. Outra situação é aquela com a qual me defrontei: sem perguntar sobre tal aspecto da intimidade, ouvi mais de uma vez confidências sexuais de homens e de mulheres. Ainda que eu não estivesse pesquisando a sexualidade, não ignorava como tal dimensão estava imbricada às questões do trabalho, da religião, da família e do esporte, dizendo respeito aos papéis de gênero e aos padrões morais, às performances masculinas e aos valores da virilidade e da malandragem. O tema da sexualidade emergia como central nos relatos de "traições" e sobre "cornos". ${ }^{17}$

Mas há ainda outros aspectos relativos ao contexto do sonho que merecem ser explorados. Depois de ter enfrentado problemas de saúde, naquela ida a campo eu ainda me recuperava de uma cirurgia. Parece que transferi uma incisão para o corpo do informante, localizando-a na parte mais simbólica da sua masculinidade. Mas a angústia da castração evidencia também outros dramas. Em conversas anteriores, meu informante havia manifestado profunda tristeza pelo fechamento recente da mina de subsolo na qual trabalhava. Depois disso, passou a atuar na superfície, mas já não se sentia "um mineiro de verdade", condição que, na cultura local, está ligada ao trabalho subterrâneo. Aquela ruptura em sua vida correspondia a um sentimento de perda de seu valor. Assim, parece-me que o sonho da castração remete ainda ao sentimento de impotência daqueles homens em oporem-se às mudanças no seu destino. É como se o fim da mina tivesse lançado cada qual à sua sorte, à

${ }_{17}$ Ver Pitt-Rivers (1983) e Fonseca (2000), entre outros.

Horizontes Antropológicos, Porto Alegre, ano 15, n. 32, p. 217-246, jul./dez. 2009 
sua solidão, com o fim da camaradagem do subsolo. Menos mineiros, eles se sentiam menos homens. ${ }^{18}$ Tinham sido desonrados. ${ }^{19}$

\section{De vulnerabilidades: uma "brasileira" em campo francês}

Outras situações nas quais fui "afetada" pela etnografia deram-se durante meu estágio de doutorado, na França, no primeiro semestre de 2008. Eu havia feito uma viagem à Creutzwald, a cidade da Lorena francesa que abrigou a última mina de carvão do país, La Houve, fechada em 2004. Meses depois, retornei a essa localidade para, durante algumas semanas, realizar o trabalho de campo. Ser uma etnógrafa em terra estrangeira põe à prova paciência, persistência e determinação e nos despe de estratégias aprendidas para construção de interações que ali podem não ter grande valia. Nas notas que fiz no período considerava que a etnografia requer "uma transcendência", na medida em que atravessamos nossos medos e limitações para ir ao encontro do "outro", expondo-nos à vulnerabilidade. Dwyer (apud Mintz, 1984), diz que, para o antropólogo, estão em jogo duas espécies de vulnerabilidades: uma relacionada com os reclamos da disciplina, e outra com seu envolvimento pessoal com a pesquisa. Combinadas, fazem crescer a angústia e a tensão do pesquisador. Esses aspectos aparecem em etnografias clássicas (como a do próprio Mintz, 1979; de DaMatta, 1978, e de Foote Whyte, 2005).

Em minha primeira visita a campo, percorrendo a pé bairros operários - compostos de casas enfileiradas de tons entre o cinza e o marrom, com um pequeno jardim ao lado - me defrontei com muitas recusas nas primeiras tentativas de estabelecer contato: desconfianças em relação a uma estrangeira, aversão a evocar as lembranças difíceis da mina. Recordo-me daquele ex-mineiro de origem polonesa que me disse: "Da mina, eu só tenho más lembranças e prefiro não falar delas". Quando podia, eu tentava quebrar essas resistências falando das semelhanças com o cotidiano dos mineiros brasileiros. ${ }^{20}$ Nas casas

\footnotetext{
18 Ver Guedes (1997).

19 Ver Bourdieu (1965), Pitt-Rivers (1983) e Eckert (1991).

${ }^{20}$ Eckert (1992, p. 3), que viveu uma experiência de longa duração entre mineiros de La Grand-Combe, no Sul da França, depois de ter pesquisado uma comunidade mineira no Sul do Brasil, diz que vivenciava ao mesmo tempo um sentimento de familiarização e de estranhamento - o primeiro relacionado à continuidade do trabalho realizado no Brasil e o segundo nascido da situação de pesquisa no exterior.
}

Horizontes Antropológicos, Porto Alegre, ano 15, n. 32, p. 217-246, jul./dez. 2009 
nas quais fui, finalmente, convidada a entrar, via também o orgulho da profissão, expresso em palavras, gestos e em paredes e estantes fartamente decoradas com objetos da mina. Fui tocada pela similaridade entre os sentimentos manifestos por mineiros franceses e brasileiros, que traduziam tristeza pelo fim da mina ${ }^{21}$ e, também, o humor peculiar do subsolo. Naquela cidade, com forte presença de imigrantes, quem me abriu primeiro a porta de sua casa foi um ex-mineiro de origem iugoslava e sua mulher vietnamita. Depois, seus vizinhos, um ex-mineiro italiano e sua mulher, me inseriram generosamente em sua própria rede de relações. ${ }^{22}$ Assim, na segunda ida a campo, eu tinha chegado a mais de 25 entrevistas.

Como Mintz (1979) mencionara sobre seu começo de pesquisa em Porto Rico, ele era "o Estrangeiro", "mas não qualquer estrangeiro", e sim um americano. ${ }^{23}$ Posso considerar que algo análogo se passava no meu caso. Eu era uma "brasileira", situação na qual identidade de gênero e de nacionalidade pareciam se colar e se potencializar. Dessa dupla condição - de mulher e estrangeira - derivaria os constrangimentos que enfrentei. Diferentemente da experiência de Minas do Leão em que a questão de gênero, ela mesma, parecia ocasionar desconfortos, na Lorena francesa o estatuto de mulher se combinava ao de "brasileira". Tal associação impedia que se fizesse a leitura da cada categoria em separado, embora fosse provável que, aos olhos de uns, ressaltasse mais o fato de eu ser uma estrangeira, e de outros, a condição feminina.

Pode-se evocar o que Octavio Paz (1999) escreveu a propósito da cultura mexicana. Ele dizia que a mulher "é o enigma". Como o homem de raça e o estrangeiro, "ela atrai e repele" (Paz, 1999, p. 73). Quando se considera então essa dupla condição de mulher e de estrangeira, estão multiplicadas curiosidades e desconfianças. Pitt-Rivers (1983, p. 153-154, tradução minha) adota definição similar: "O estrangeiro é, por essência, [...] o incógnito"; ele é, antes de tudo, "alguém em quem não se pode confiar". As pessoas do lugar devem construir sobre ele "sua própria opinião". Embora com uma estadia bem mais curta do que a do trabalho no Brasil, minha permanência acionava a construção

${ }^{21}$ Ver Eckert (1991).

${ }^{22}$ Tive a sensação de ter encontrado um "lar" entre os italianos, pelo fato de meu bisavô paterno ter emigrado da Itália para o Brasil.

${ }^{23}$ Mintz (1979, p. 28) conta sobre o "nervosismo" e o "medo" que sentia quando chegou a Porto Rico, zona afetada pela ocupação americana. Não dominava bem o espanhol e, ainda por cima, era um americano.

Horizontes Antropológicos, Porto Alegre, ano 15, n. 32, p. 217-246, jul./dez. 2009 


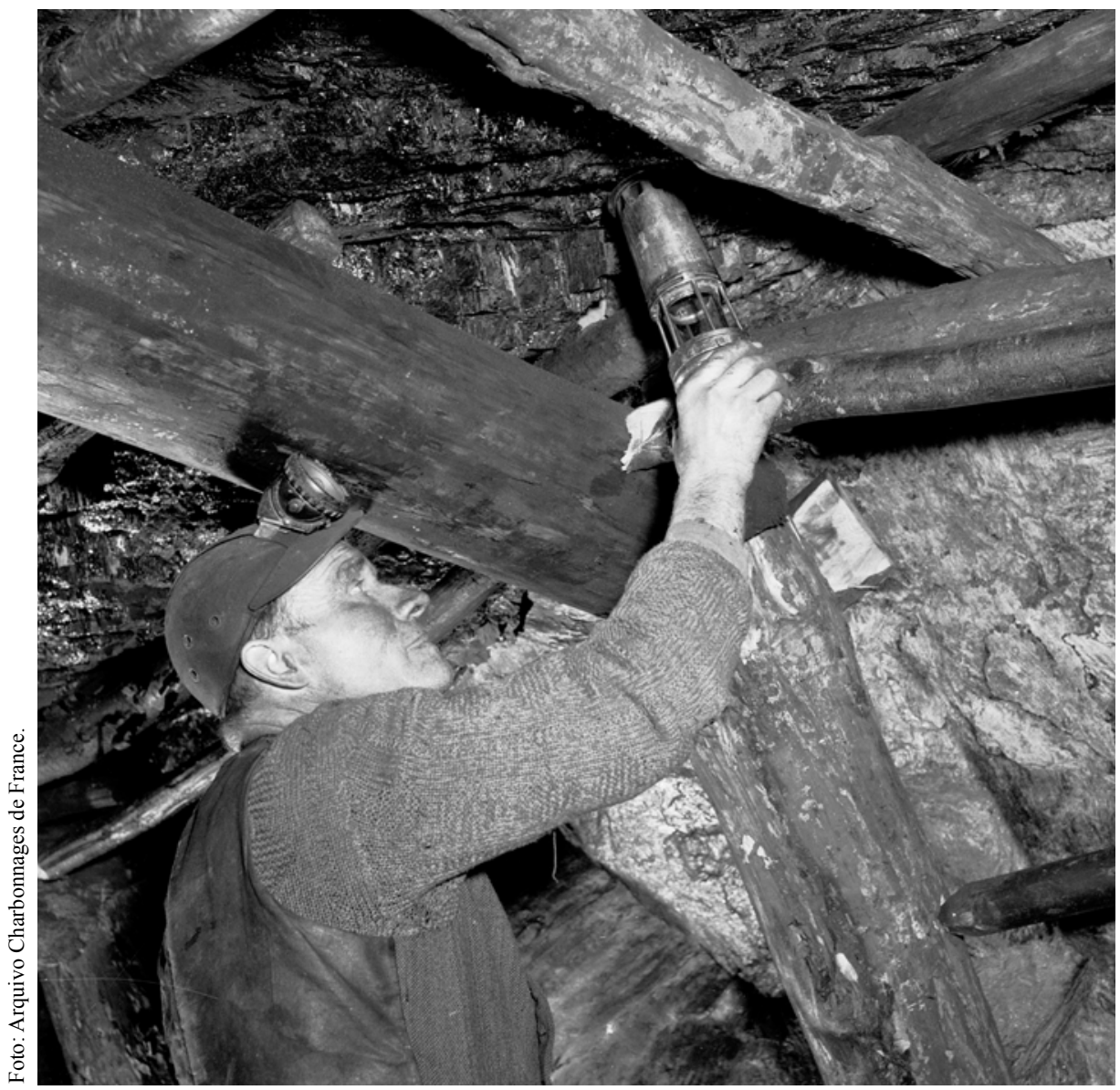

Figura 1. Mineiro de subsolo na França.

de uma "reputação", que podia confirmar ou desfazer visões sobre uma "brasileira". Nem sempre isso estava em jogo de forma estereotipada. Apenas em quatro ou cinco casos houve realmente um mal-estar derivado dessa condição. Em situações em que a conversa era atravessada por forte densidade política (em entrevistas com sindicalistas ou militantes de esquerda), o estatuto de pesquisadora latino-americana interessada em trajetórias operárias evocava empatia e solidariedade. Em interações familiares, a atenção se focava em minha

Horizontes Antropológicos, Porto Alegre, ano 15, n. 32, p. 217-246, jul./dez. 2009 
nacionalidade e trajetória pessoal (estudante, filha de trabalhador, bisneta de imigrantes). Às vezes, ser estrangeira era uma vantagem: há menos riscos em se contar a própria história a quem partirá a um país distante. Isso foi expresso quando um informante permitiu que eu fizesse cópia do dossiê de saúde de seu pai que indicava a presença da silicose, ainda que ele tivesse obtido os documentos quando trabalhava num órgão de seguridade social representando a companhia. A mulher dele acabou por se tranquilizar: "Mas é para levar para o Brasil, não é? Então, não há problema."

Algumas situações embaraçosas, no entanto, estavam relacionadas a referências verbais e/ou gestuais evocadas diante de uma "brasileira". Num desses episódios, eu conduzia a entrevista na residência de um casal. $\mathrm{O}$ exmineiro, de pouco mais de 50 anos, havia se aposentado na mina ocupando uma posição de chefia. Sua casa, bem arrumada e decorada, mantinha uma ambiência fria, reservada, mesmo tom que predominou na interação. Durante a entrevista, sua mulher precisou sair e continuamos a conversa. O constrangimento ocorreu no final, quando entreguei a ele um papel com meu nome, $e$-mail e a referência "antropóloga brasileira", como costumava fazer. Ele lascou a questão: "Por que 'brasileira'?" Sem entender, eu reafirmei que era "brasileira". Ele me disse que "eu não deveria fazer propaganda disso", pois podia ser perigoso estando hospedada sozinha num hotel. Explicou: "As brasileiras eram a fantasia sexual da nossa geração. As brasileiras... e as suecas". Depois, informou que um amigo, sabendo que uma brasileira estaria em sua casa, insistiu para ir até lá, ao mesmo tempo em que lhe demandava sobre minhas características. Meu interlocutor teria dito que eu era "atraente", mas estava ali "fazendo meu trabalho". Na saída, quando lhe perguntei se podia fazer uma foto sua diante da casa, adquirida da companhia, sugeriu: "Eu é que devia fazer uma foto tua!"

Mais de uma vez, a referência à minha nacionalidade parecia ser o salvoconduto para uma mudança de tom de informantes, por vezes indagando sobre minha situação civil. Ainda que tivesse que arcar com maiores riscos, continuei a dizer que era "solteira". Durante a primeira entrevista, realizada no café do hotel com um antigo contramestre da mina, de quase 80 anos, vivi momentos de mal-estar. Quase no final da entrevista, depois de olhar atentamente para os lados, certificando-se que não era ouvido por outros, meu interlocutor baixou bastante a voz para me dizer algo que fazia referência a "meu quarto". Mais do que escutado, eu havia entendido o tom malicioso da observação. Muito 
desconfortável, aproveitei meu domínio imperfeito do idioma: "O senhor está me perguntando se estou bem instalada neste hotel?" Ele confirmou. Eu respondi que, apesar de pequenos inconvenientes, considerava o hotel adequado. A atendente do café aguardava um sinal de que meu trabalho estava no fim para elevar o volume da música. Em certo momento, ela borrifou perfume entre as mesas ocupadas por casais. Quando meu interlocutor se disse admirado de minha "coragem" de estar ali, sozinha e sem conhecer ninguém, respondi que, assim como a vida de mineiro tinha seus riscos, a de antropóloga tinha os seus próprios. "Formidável!", ele disse, ao se retirar.

Num final de tarde, enquanto eu entrevistava no café do hotel um filho de ex-mineiro de origem iugoslava, vivi outra cena constrangedora. Diante do telefonema de sua mulher e da pergunta sobre onde ele se encontrava, o rapaz respondeu num tom provocativo: "Estou no bar do hotel sendo entrevistado por uma brasileira!" Eu pude ouvir o que ela disse do outro lado da linha: "Por uma brasileira?!!!" Meia hora depois, a mulher ciumenta aparecia diante da mesa do bar com a filha pequena nos braços, e praticamente cuspia as palavras que dirigia ao marido: "Ela é bonita... Então é por isso que tu não tens hora para voltar para casa?!". Ainda furiosa, me perguntou quando eu havia chegado à cidade. Eu tentei acalmar os ânimos sugerindo que ela participasse da entrevista. Ela continuou a atacar o marido e, indiretamente, a mim. Aceitou posar para uma fotografia familiar, mas antes de saírem ainda me perguntou sobre quando eu iria embora da cidade.

Segundo ouvi, o imaginário sobre "brasileiras" teria se alimentado de imagens televisivas de mulheres portando trajes sumários no carnaval e nas praias verde-e-amarelas. Atravessando essas imagens estavam representações sobre a "sensualidade", a "simpatia", "a beleza" e a "permissividade sexual" atribuídas aos brasileiros. Em seu estudo sobre a cultura sexual no Brasil, o antropólogo americano Richard Parker (1991) aborda alguns "mitos de origem peculiares". Conforme o autor, a sensualidade brasileira é celebrada e se relaciona, no nível mais profundo, com o que significa ser brasileiro. Essa imagem seria apresentada pelos brasileiros a si mesmos e para o mundo estrangeiro. Mas haveria certa ambiguidade nessas representações devido às contradições, às diferentes lógicas que estruturam o universo sexual no Brasil (Parker, 1991, p. 244-245).

Noutra ocasião, eu estava no café esperando um informante quando percebi que era observada por um sujeito no balcão. Algum tempo depois, ele foi 
até a minha mesa e apresentou-se como um congé charbonnier, ou seja, um mineiro que havia trabalhado até o fechamento da mina e que agora recebia $80 \%$ do salário para permanecer em casa, à disposição da empresa, até a idade da aposentadoria. Era por volta do meio-dia e percebi que meu interlocutor havia bebido. Sugeri que a entrevista fosse feita na manhã seguinte. Ele havia dito que era divorciado. Depois de me certificar com a atendente do café de que não haveria "perigo", marquei a entrevista na casa dele. $\mathrm{O}$ apartamento era decorado com objetos da mina, diplomas de honra e fotografias feitas no subsolo. Eram nove horas da manhã e meu interlocutor já cheirava a álcool, embora estivesse mais sóbrio que no dia anterior. Sua atitude, porém, não me deixou nada à vontade. Sentado próximo, olhava-me fixamente, de maneira estranha. Senti-me tensa e retesada durante toda a entrevista, conduzida por mim de maneira bastante formal. A pretexto de mostrar imagens da mina, exibiu fotos suas com uma mulher seminua que, de relance, pareceu-me uma prostituta. Surpresa, perguntei: "Isso aqui era carnaval?" "Não, era outra coisa", respondeu. Noutra foto, havia um rosto de mulher (aparentando ser prostituta) com os lábios contraídos para um beijo. Sobre a fotografia, uma marca de batom e a dedicatória: "Ao meu mineiro." ${ }^{24}$ Dessa vez, não fiz comentários. Se uma entrevista realizada em outra língua, que não o idioma materno, demanda esforço, nada se comparava ao cansaço que sentia ao sair dali. Doíam-me os músculos da face e dos ombros contraídos pela tensão. A entrevista que faria depois, com um sindicalista, ajudaria a dissipar aquela atmosfera pesada.

No período em que fiquei hospedada com um casal de informantes na cidade vizinha de Freyming-Merlebach, minha presença engendraria um contorno mais "familiar". Na chegada, participaria de um almoço pelo aniversário de ordenação de um padre católico. Havia três lugares reservados à mesa com os devidos nomes. No lugar que me era destinado, meu nome de batismo era completado pelo sobrenome daquela família, sugerindo que eu era recebida "como uma filha". Mais do que à diferença de idade, essa atribuição parecia estar relacionada à minha condição de estudante, similar à de seus filhos, e ao fato de eu ser uma mulher solteira e estrangeira, o que poderia remeter a certa vulnerabilidade - a outra face atribuída à mulher e ao estrangeiro, ao lado da suspeição que paira sobre eles. Ainda que a trajetória do marido, engenheiro

${ }^{24}$ No francês: À mon mineur à moi. 
aposentado da mina, fosse mais relacionada ao meu tema de pesquisa, coube à esposa, professora de inglês, me apresentar a famílias conhecidas de mineiros. Além da condição de gênero, havia outro liame comum: o das origens familiares. Ela era filha de um ex-mineiro italiano que foi trabalhar nas minas francesas e, nessa condição, apresentou-me a outros descendentes de italianos. Seu marido, filho de ex-mineiro esloveno, havia me apresentado a um antigo mineiro com mesma origem e que se tornara um "historiador local".

Como nos lembra Pitt-Rivers (1983), a lei da hospitalidade é fundada sobre a ambivalência - o hóspede pode estar a meio do caminho entre o estrangeiro suspeito e o membro da comunidade. Devereux (1980) acentuava que a aceitação pelo pesquisador do papel que lhe é atribuído pode restringir seu campo de visão. Acolhida gentilmente como hóspede, estabeleci novas e ricas - interações a partir das indicações de meus anfitriões, mas enfrentei eventualmente o risco de ver limitada a fronteira de minhas investigações, devido à sua condição social e posições políticas. ${ }^{25}$ Em minha experiência na Lorena houve assim duas fases. Na primeira, passei por constrangimentos relativos ao gênero e à nacionalidade, mas também alarguei meu campo de visão. Na segunda, hospedada por informantes, estava assessorada e "protegida", mas sujeita às regras da hospitalidade.

\section{0 sonho da casa-mina}

De volta a Paris, entre a primeira e a segunda ida a campo, tive um sonho que traduzia percepções acumuladas. Segue o relato do sonho tal como o registrei no diário.

Havia uma festa na rua e um operário dispôs sobre o muro algumas comidas e bebidas. $\mathrm{O}$ que parecia ser um muro era, na verdade, o teto da casa daquele rapaz, já que ele morava nos subterrâneos. Ele convidou-me para uma visita. Era preciso entrar num poço apertado para chegar até lá. Depois de passar por estreitas galerias, finalmente chegamos à casa, onde vivia ele, a mulher e uma filha

${ }^{25}$ Quando o engenheiro me levou à casa do "historiador local", durante minha primeira visita a campo, justificou que seria melhor que eu ouvisse alguém "neutro", pois os sindicalistas me dariam uma "visão parcial'. A posição que ocupara na companhia certamente determinava esse interesse. Entre os sindicalistas, o engenheiro era considerado como "de direita".

Horizontes Antropológicos, Porto Alegre, ano 15, n. 32, p. 217-246, jul./dez. 2009 
pequena. Eles me convidaram para entrar na sala de poucos móveis. Sentei-me no sofá e notei que, vista de dentro, a casa não possuía janelas. Havia o desenho delas nas paredes internas de alvenaria, caiadas de branco, mas o espaço era inteiriço. Essa percepção me trouxe certo desconforto. Havia alguns quadros e enfeites na parede em frente.

A dona da casa me convidou então para conhecer o quarto do casal. Eu a acompanhei, percebendo que caminhávamos sobre o chão batido. No lugar onde estaria a cama havia apenas uma estrutura de ferro dobrada na parede, um pouco alta. A mulher me explicou que eles colocavam ali o colchão, naquela altura, porque o mar poderia invadir a casa. Pelo que entendi de sua explicação, quando havia uma inundação, eles dormiam sobre as águas. Quando voltamos para a sala, brinquei com a filha pequena do casal. Depois, a mãe foi para outro cômodo trocar as fraldas da menina. Recordo-me que havia uma velha visitando-os; era uma vizinha, viúva, e parecia ter passado a tarde ali. Antes de ir embora, ela protegeu a própria cabeça com uma roupa íntima que pertencera ao marido ao passar pela fenda estreita daquela galeria.

Depois, meus anfitriões me convidaram para conhecer o pátio. Saímos e vi que havia muito verde, gramado, árvores e sol batendo. Olhei então para cima e observei que havia um teto de cimento encobrindo tudo, mas que ainda assim (com a propriedade da transparência) permitia entrar a luz do sol. Era um sol filtrado e havia uma natureza que crescia naquele aprisionamento. Eu disse à mulher: "Se ao menos se pudesse furar este teto, não é?" Acho que ela não deu resposta. Se deu, era resignada. Ali era o seu quintal, o seu jardim. Não havia nela qualquer inquietação pelo fato de aquele universo estar cercado por uma camada de cimento.

Então, saí com o casal para o pátio comum, para a "vizinhança". Era uma área maior, que me parecia bastante poluída, com lixo e com rejeitos escuros (penso que fosse de carvão). Muitos garotos já crescidos e sujos estavam brincando. Havia provocações e enfrentamentos entre eles, dos quais era necessário se refugiar. Senti que havia risco em permanecermos ali. Saímos daquele local e passamos a andar em volta da casa, cujas paredes, agora, pareciam ser de madeira, em tons desbotados. Neste momento, eu podia ver que era uma casa simples, talvez com duas janelas (vistas do lado de fora) de cada lado. Na extensão da casa, havia uma plantação de tomates, com frutos maduros e vermelhos, circundando os dois lados da calçada. (Diário de campo, 22 de junho de 2008).

Ao acordar, pensei nas vilas mineiras francesas, mas creio que essas imagens dizem também de outros contextos. Sugiro apenas alguns aspectos. No sonho, como nas etnografias, é o elemento masculino que me insere no 
mundo da mina. Os homens estão representados pelo trabalhador que vive com a família no subterrâneo, mas que vai para a festa no exterior, circulando entre diferentes mundos; assim como pelos garotos que exercitam, na área da vizinhança, sua força e sua virilidade em provocações e jogos brutos. Como uma espécie de inversão, no sonho as mulheres é que permanecem no subsolo, enquanto que os homens saem à superfície. Na época da mina (em Minas do Leão e em Creutzwald), muitas mulheres de mineiros permaneciam em casa, enquanto os homens iam para o subsolo. No sonho, as mulheres estão no "interior", que não é apenas o espaço da casa, mas o da terra, configurando uma exacerbação do princípio feminino - tal como na análise de Bourdieu (1965) sobre a cultura cabília, em que a oposição dentro-fora surge como fundamental, como água-fogo, vulnerabilidade-proteção, etc. No sonho, a esposa é quem me revela o risco de inundações. A mulher idosa já não conta com a "proteção" do marido, mas parece evocá-la ao carregar uma roupa íntima dele e a posicionar sobre a cabeça no momento de atravessar a fenda estreita da galeria.

Dias depois do sonho, voltei a campo. Eu me perguntava por que via aquele mundo simbolicamente no interior da terra. O fechamento ${ }^{26}$ representado pelo "teto cimentado" e as paredes "sem janelas", com o fim da mina, estaria relacionado à falta de horizontes? À impossibilidade de essas famílias se pensarem fora da atividade? Às minhas próprias dificuldades de entrever um desenrolar para sua saga? Alguns elementos do sonho estariam presentes na observação seguinte: tais como os jardins operários, os relatos sobre tragédias passadas e a preocupação com a violência de jovens sem trabalho, especialmente de filhos de imigrantes. Outro drama dizia respeito à situação dos congé charbonniers - como foi dito, homens que saíram na mina na ocasião de seu fechamento e que permanecem em casa, à disposição da companhia. Cerca de 400 funcionários se encontravam nessa situação. Como estão impedidos de ter outro emprego, os relatos indicavam um aumento de depressões, de alcoolismo, de divórcios e até de suicídios. Entrevistei 12 trabalhadores nessa categoria. Salvo num caso - o do mineiro com problemas de alcoolismo, mencionado antes, que dizia estar satisfeito porque "não precisava mais acordar cedo" -,

${ }^{26}$ Vilas mineiras são, por vezes, definidas como "fechadas sobre si mesmas", caracterizando as políticas paternalistas das companhias, destinadas a fixar populações. Ver Eckert (1991); Schwartz (2002).

Horizontes Antropológicos, Porto Alegre, ano 15, n. 32, p. 217-246, jul./dez. 2009 


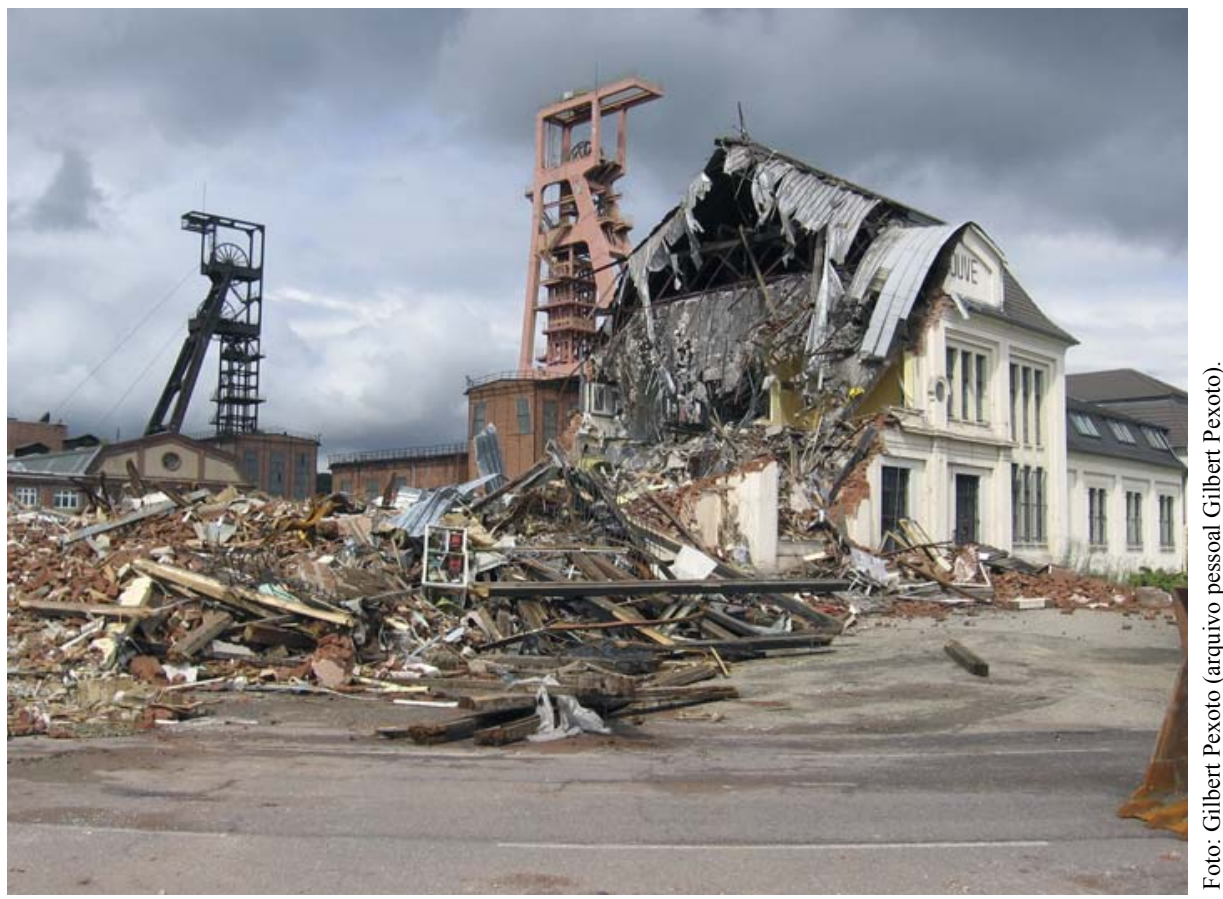

Figura 2. Demolição da sede da mina La Houve, em Creutzwald, na França.

os demais lamentavam a perda de dignidade. Como resumiu um sindicalista da CGT: "Antes éramos admirados pela sociedade, agora somos vistos como quem ganha sem nada fazer". Ele se referia a uma honra ferida da profissão.

O antropólogo Manuel Vale de Almeida (1994), num artigo sobre questões de gênero num vilarejo em Portugal, analisava que os homens de lá experimentavam "certo horror de se encontrar em casa", sentiam que ficar em casa lhes "fazia mal", fosse porque simbolizava o desemprego, a preguiça ou a dependência da mulher. Quando reli essa passagem, fui remetida de volta ao sonho da casa-mina. Se a identidade do operário (assim como a casa, no sonho) está na mina, mas não há mais mina, então há uma dissolução do seu valor. Confinados a casa, enfrentando o tédio (o "horror ao doméstico"), esses homens podem sentir o espaço do lar como um abismo - mais fundo e labiríntico do que a mina. 


\section{Considerações finais}

A partir da discussão de questões de gênero e de subjetividade envolvidas na pesquisa etnográfica entre mineiros de carvão, meu objetivo neste artigo foi refletir sobre a interação entre uma pesquisadora mulher e seus interlocutores homens em dois universos, Minas do Leão, no Brasil, e Creutzwald, na França. É na esteira das "perturbações” vivenciadas em campo - no primeiro caso derivadas do estatuto de ser uma "mulher solteira", e no segundo de ser estrangeira (e "brasileira") - que localizo certas produções da subjetividade, tais como os sonhos, fornecendo indicações que podem ajudar a elucidar aspectos da experiência. Tanto no sonho acerca da "castração" como no da "casa-mina" parecem estar presentes, além de elementos sobre a identidade masculina, angústias relacionadas com o fim da mina de subsolo. Se essas imagens dizem de minhas emoções durante a pesquisa, traduzem também os contextos em que eu me encontrava e sentimentos daqueles com quem convivi. De um lado, estão os relatos de mineiros evocando a passagem de um cotidiano no subsolo para o da superfície. De outro, o esforço para trazer à "superfície" do texto etnográfico vivências relativas às profundezas de minha própria subjetividade durante o trabalho de campo.

\section{Referências}

BAILEY, F. G. Gifts and poison: the politics of reputation. Oxford: Basil Blackwell, 1971.

BALANDIER, G. Histoire de vie, mode d'emploi. Le Monde, Paris, p. 22, 28 juin. 1991.

BEAUD, S.; WEBER, F. Guide de l'enquête de terrain: produire et analyser des donnés ethnographiques. Paris: La Découverte, 1998.

BECKER, H. S. Métodos de pesquisa em ciências sociais. São Paulo: Hucitec, 1993.

BOURDIEU, P. O sentimento de honra na sociedade cabília. In: PERISTIANY, J. G. (Org.). Honra e vergonha: valores das sociedades mediterrâneas. Lisboa: Fundação Calouste Gulbenkian, 1965. p. 159-195. 
BOURDIEU, P. Esboço de auto-análise. São Paulo: Companhia das Letras, 2005.

BOZON, M. Observer l'inobservable: la description e t l'analyse de l'activité sexuelle. In: BAJOS, N. et al. (Dir.). Sexualité et Sida: recherches en sciences sociales. Paris: ANRS, 1995. p. 39-56.

CALDEIRA, T. P. R. Uma incursão pelo lado "não respeitável" da pesquisa de campo. In: TRABALHO e cultura no Brasil. Recife: Anpocs: CNPq, 1981. p. 332-354. (Ciências Sociais Hoje, n. 1).

CARDOSO DE OLIVEIRA, R. O trabalho do antropólogo. Brasília: Paralelo 15; São Paulo: Unesp, 2000.

CIOCCARI, M. Ecos do subterrâneo: estudo antropológico do cotidiano e memória da comunidade de mineiros de carvão de Minas do Leão (RS). Dissertação (Mestrado em Antropologia Social)-Instituto de Filosofia e Ciências Humanas, Universidade Federal do Rio Grande do Sul, Porto Alegre, 2004.

CIOCCARI, M.; CABALLERO, I.; FIGURELLI, M. F. Dos constrangimentos, das identidades e dos afetos em três universos etnográficos. In: JORNADA DE ETNOGRAFÍA Y MÉTODOS CUALITATIVOS, 5., 2007, Buenos Aires. V Jornadas... Buenos Aires: Centro de Antropologia Social/Instituto de Desarrollo Económico y Social, 2007. 1 CD-ROM.

COMERFORD, J. Como uma família: sociabilidade, territórios de parentesco e sindicalismo rural. Rio de Janeiro: Relume-Dumará, 2003.

DAMATTA, Roberto. O ofício de etnólogo, ou como ter anthropological blues. In: NUNES, E. de O. (Org.). A aventura sociológica: objetividade, paixão, improviso e método na pesquisa social. Rio de Janeiro: Zahar, 1978. p. 23-35.

DEVEREUX, G. De l'angoisse à la méthode dans les sciences du comportement. Paris: Aubier, 1980.

DUARTE, L. F. D. Da vida nervosa nas classes trabalhadoras urbanas. Rio de Janeiro: Graal, 1986. 
DUARTE, L. F. D. Identidade social e padrões de agressividade verbal em um grupo de trabalhadores urbanos. In: LEITE LOPES, J. S. (Org.). Cultura e identidade operária. Rio de Janeiro: Marco Zero, 1987. p. 171-201.

DURHAM, E. A reconstrução da realidade. São Paulo: Ática, 1978.

ECKERT, C. Os homens da mina: um estudo das condições de vida e representações dos mineiros de carvão em Charqueadas/RS. Dissertação (Mestrado em Antropologia Social)-Instituto de Filosofia e Ciências Humanas, Universidade Federal do Rio Grande do Sul, Porto Alegre, 1985.

ECKERT, C. Une ville autrefois minière: la Grand-Combe, étude d'Anthropologie Sociale. Thèse (Doctorat en Anthropologie Sociale)Université Paris V, Sorbonne, Sciences Humaines, Paris, 1991.

ECKERT, C. Relato de uma pesquisa etnográfica na França. Revista do Instituto de Filosofia e Ciências Humanas, Porto Alegre, v. 15, p. 9-30, jul. 1992.

FAVRET-SAADA, J. Être affecté. Gradhiva, Paris, v. 8, p. 3-9, 1990.

FONSECA, C. Família, fofoca e honra: etnografia de relações de gênero e violência em grupos populares. Porto Alegre: Editora da UFRGS, 2000.

FOOTE WHYTE, W. Sociedade de esquina. Rio de Janeiro: Jorge Zahar, 2005.

GUEDES, S. L. Jogo de corpo: um estudo de construção social de trabalhadores. Niterói: Eduff, 1997.

HOGGART, R. As utilizações da cultura: aspectos da vida cultural da classe trabalhadora. Lisboa: Editorial Presença, 1973.

KIMMEL, M. S. A produção simultânea de masculinidades hegemônicas e subalternas. Horizontes Antropológicos, Porto Alegre, ano 4, n. 9, p. 103-117, out. 1998. 
KNAUTH, D. R. Morte masculina: homens portadores do vírus da Aids sob a perspectiva feminina. In: DUARTE, L. F. D.; LEAL, Ondina. F. (Org.). Doença, sofrimento, perturbação: perspectivas etnográficas. Rio de Janeiro: Fiocruz, 1998. p. 183-198.

LEAL, O. F.; BOFF, A. M. Insultos, queixas, sedução e sexualidade: fragmentos de identidade masculina em uma perspectiva relacional. In: PARKER, R.; BARBOSA, R. M. (Org.). Sexualidades brasileiras. Rio de Janeiro: RelumeDumará: Abia: IMS/Uerj, 1996. p. 119-135.

LEITE LOPES, J. S. A tecelagem dos conflitos de classe na cidade das chaminés. São Paulo: Marco Zero:Ed. UnB, 1988.

LEITE LOPES, J. S.; ALVIM, R. Uma autobiografia operária: a memória entre a entrevista e o romance. Estudos Avançados, n. 37, p. 105-124, set./ dez. 1999.

MACHADO, P. S. Entre homens: espaços de gênero emuma pesquisa antropológica sobre masculinidade e decisões sexuais e reprodutivas. In: BONETTI, A.; FLEISCHER, S. Entre saias justas e jogos de cintura. Florianópolis: Editora Mulheres; Santa Cruz do Sul: Edunisc, 2007. p. 155-184.

MALINOWSKI, B. Coral Gardens and their Magic. London: George Allen \& Unwin, 1935.

MALINOWSKI, B. Argonautas do Pacífico Ocidental. São Paulo: Abril Cultural, 1984.

MALINOWSKI, B. Um diário no sentido estrito do termo. Rio de Janeiro: Record, 1989.

MALVA, C. Ma nuit au jour le jour. Paris: François Maspero, 1978.

MINTZ, S. W. Taso: la vie d'un travailleur de la canne. Paris: François Maspero, 1979.

MINTZ, S. W. Encontrando Taso, me descobrindo. Dados: Revista de Ciências Sociais, Rio de Janeiro, v. 27, n. 1, p. 45-58, 1984. 
NASH, J.; ROJAS, J. He agotado mi vida en la mina: autobiografía de un minero boliviano. Buenos Aires: Nueva Visión, 1976.

PALMEIRA, M. Apostas eleitorais: notas etnográficas. Rio de Janeiro: PPGAS/Museu Nacional, 2006. Mimeo.

PARKER, R. G. Corpos, prazeres e paixões: a cultura sexual no Brasil contemporâneo. São Paulo: Best Seller, 1991.

PAZ, O. El laberinto de la soledad. México: Fondo de Cultura Económica, 1999.

PITT-RIVERS, J. Anthropologie de l'honneur: la mésaventure de Sichem. Paris: Le Sycomore, 1983.

SCHWARTZ, O. Le monde privé des ouvriers. Paris: PUF, 2002.

VALE DE ALMEIDA, Miguel. Émotions rimées: poétique et politique des émotions dans un village du sud de Portugal. Terrain, n. 22, mars. 1994. Disponível em: <http://terrain.revues.org/document3082.html>. Acesso em: 28 fev. 2006.

VISEUX, A. Mineur de fond. Paris: Plon, 1991.

Recebido em: 16/02/2009

Aprovado em: 24/03/2009 